\title{
EFFECT OF BRAND EQUITY AND MARKETING MIX ON CUSTOMER SATISFACTION AND IMPACT ON CUSTOMER LOYALTY
}

\author{
Nani Sriyani \\ Universitas Pamulang \\ nani_sriyani@yahoo.com
}

\begin{abstract}
This research is about the activities carried out by PT Bank ICB Bumiputera, Tbk in the use of brand strategy and service marketing mix by looking at its effect on customer loyalty through customer satisfaction.Data processing was done by using path analysis, this research is quantitative with the number of respondents as many as 100 respondents. The results of the first study showed that there is a significant influence between brand equity and marketing mix on customer satisfaction. The results of the second study show that there is a significant influence of brand quantity, service marketing mix and customer satisfaction on customer loyalty. This research is important information for PT Bank ICB Bumiputera by considering the variables mentioned above so that it can carry out marketing activities that will increase market share and the number of customers.
\end{abstract}

Keywords: Brand Equity; Service Marketing Mix; Customer Satisfaction and Customer Loyalty

\section{INTRODUCTION}

In a business activity there must be a part that carries out marketing activities, marketing activities interact directly with the public and consumers, then the success of marketing activities will determine the progress and development of good or failure of the business being run. In the implementation of modern marketing activities, producers don't merely produce goods that are needed, determine selling prices and create distribution channels.

In banking business activities are businesses that have high regulations because one of the ways to run a banking business is collecting public funds, this is very dangerous if it is not controlled in the management of public funds. Experience has shown that the

collapse of a bank is mostly due to careless lending which has caused bad loans and burdens the bank's finances.

Aside from bad loans, a large cost burden is one of the problems that must be faced by banks. The biggest expense in banking business activities is the interest fee, which is the cost that must be paid by the bank to the customer who keeps the funds in the bank, namely the payment of interest on Demand Deposits, Savings and Deposits. Therefore, almost all banks strategy is to increase savings customers with a gimmick of various attractive prizes, this is to reduce interest costs so as to increase income.

The success of a bank is determined by its customers. Because of the 
importance of these customers the bank must create new customers, win customers' hearts from competitors and keep existing customers. Various strategies are implemented to maintain the level of customer satisfaction that will foster customer loyalty.

In 2009 PT. Bank Bumiputera changes in share ownership so that there is a change from the name, namely the identity and the company logo changes as PT. Bank ICB Bumiputera. With the name change, there has been a declining trend in the number of customers in the Jabodetabek Regional Savings account since the change in name, where in 2010 the number of 122,887 customers decreased $19 \%$ in 2011 to 99,509 and again declined $5 \%$ in 2012 to 94,204 , but in 2013 it increased 9\% to 102,993

Many things happened to the ICB Bumiputera bank after the change of name and $\log$ o made this a very interesting item for further review and thorough both in terms of the influence of the new brand and its marketing strategy. To be able to gain banking market share, retain customers and maintain customer loyalty, it is necessary to measure customer response related to brand equity, marketing mix that has been done and the level of customer satisfaction and loyalty.

\section{THEORETICAL REVIEW}

Anindhyta Budiarti, Surachman, Djumilah Hawidjojo \& Djumahir.2013. The Budiarti et al., research is an explanatory study with a sample of 350 Garuda Indonesia Airline international passengers at several Indonesian International airports in Jakarta Soekarno Hatta, Ngurah Rai Denpasar, Hong Kong airport and Singapore Changi airport.

The design sampling used is nonprobability accidental sampling with the criteria for passengers who manage international flights at least twice a year,
Indonesian citizens and also non-Garuda airlines. Exogenous variables are advertising and service quality, while endogenous variables are brand equity and customer satisfaction with analysis using a two-way Path Analysis. The results of this study are presented as follows:

1) Advertising and service quality will increase brand equity, service quality is very dominant affect brand equity compared to advertising.

2) Quality of service and brand equity will increase consumer satisfaction, while the effect of brand equity is stronger than service quality.

Quality of service, brand equity and customer satisfaction will increase consumer loyalty. Garuda Indonesia Airline passenger loyalty will remain high if supported by brand equity and high satisfaction, which is generated by the quality of services and intensive advertising programs.

\section{RESEARCH METHOD}

The research is conducted by using quantitative research method. The instrument method used was the survey method, which was collected through a questionnaire with several written questions addressed to respondents. The survey used was a cross-sectional survey (Kountur, 2005: 106) where data collection was carried out only at certain times in a few days or several weeks. The collection of data in conducting this research was carried out for one semester.

To get the number of samples surveyed the author uses the formula 'Taro Yamane' with a precision value of $10 \%$.

\section{Data collection technique Primary Data}

Primary data is obtained directly when conducting research in the field with 
the intended respondent through the distribution of questionnaires to depositors at PT Bank ICB Bumiputera, Tbk in the Greater Jakarta area. The questionnaire or question sheet distributed was designed based on a Likert scale, where the questionnaire contained several questions to reveal the object to be known.

\section{Secondary Data}

Secondary data is research data obtained by researchers, not directly, but is obtained through other media such as library research and the necessary data is also obtained from journals, books, articles from print media, internet and company archives related to Brand equity, service marketing mix, customer satisfaction and customer loyalty.

\section{Analysis Method}

To investigate effect brand equity has, the marketing mix is on customer satisfaction and customer loyalty using Path Analysis.

Path analysis model (path analysis) is used to describe the phenomena that are studied, can be said to be the problem of research. Besides that in order to predict the dependent variable (Y) based on the value of the independent variable $(\mathrm{X})$, in this case the prediction using this path analysis is qualitative.

\section{Descriptive Analysis}

With the help of a computerized SPSS program, steps to describe the data from the sample of each variable can be done. Furthermore, an overview of the profile of respondents related to income, education, employment, sex, age and age can be seen from the results of the SPSS.

\section{Validity and Reliability Test}

Reliability and validity test are needed before respondents are given a questionnaire to be filled out.

\section{Classical Assumption Test}

Regarding assumptions violations include heteroscedasticity (heteroscedasticity),multicollinearity (multicollinearity), and autocorrelation (autocorrelation). If the above assumptions are fulfilled then it will assess the BLUE meter's value

\section{Hypothesis testing Statistic test}

T test

Test the coefficient of the estimating variable or the independent variable. Estimating variables need to be significantly different from zero or P-values are very small. This test is carried out through a statistical $t$ test at an error rate of $5 \%$. This test can be done to find out whether the independent variable partially significant has an influence on the dependent variable.

F test

The $\mathrm{F}$ test is a test of the significance of the coefficients of the regression together. Testing is done to see the effect of independent variables on the dependent variable.

\section{Correlation Test}

This correlation analysis is to determine the relationship between variables to measure the strength of the relationship between brand equity, marketing mix to customer satisfaction and customer loyalty.

\section{Adjusted $\mathbf{R}^{2}$}

This coefficient is to measure how far the model's ability to explain the variation of the dependent variable. The value coefficient of determination is between zero and one. If the $\mathrm{R}^{2}$ / Adjusted $\mathrm{R}^{2}$ value is small, it indicates that the ability of the independent variables in explaining the variation of the dependent variable is limited. 


\section{RESULTS AND DISCUSSION}

\section{Tests of Validity and Reliability}

Based on the results of testing the validity and reliability, all the questions in questionnaires for indicator of brand equity, marketing mix, customer satisfaction and customer loyalty, are eligible reliability value, which indicate that all the questions declared reliable, and all values Corrected Item-Total Correlation $\mathrm{r}$ product moment> 0.374 , then all questionnaires are valid

Test of Effect of Brand Equity and Marketing Mix on Customer Satisfaction

\section{Classical Assumption Test}

1) Normality Test: It appears that the points are approaching diagonal lines, this shows that the assumption of normality is acceptable.

2) Heteroscedasticity Test: The spread of random points / not forming a certain pattern and spread around zeros means there is no problem of heteroscedasticity.

3) Multicollinearity Test: From the Correlation table, there is no value> 0.8 so there is no multicollinearity problem between independent variables

4) Autocorrelation test: DW value is 1,390 located between -2 to +2 , meaning DW falls in the area of no autocorrelation, so there is no autocorrelation in the model

Hypothesis Test Results of the Effect of Brand Equity and Mix

1) $\mathrm{T}$ Test Results of Brand Equity Variables on Customer Satisfaction. With a t value of 2.345 and the significance value obtained $0.021<0.05$ then Ho is rejected and $\mathrm{H} 1$ is accepted, meaning that there is a significant influence between brand equity variables and customer satisfaction.

2) $\mathbf{T}$ Test Results Variable Services Marketing Mix Variable to Customer Satisfaction.

Figures for research - 3.048 with (sig) obtained $0.003<0.05$ Then $\mathrm{H} 0$ rejected and $\mathrm{H} 1$ accepted. This means that there is a significant influence between variables service marketing mix to customer satisfaction

3) Test Results F Variable Brand Equity and Service Marketing Mix Together (Simultaneously) Against Customer Satisfaction

$\mathrm{F}$ arithmetic $=13,598>\mathrm{F}$ table $=2.70$ with a significance value of $0,000<0.05$ There is a significant influence between variables of brand equity and marketing mix together on Customer Satisfaction

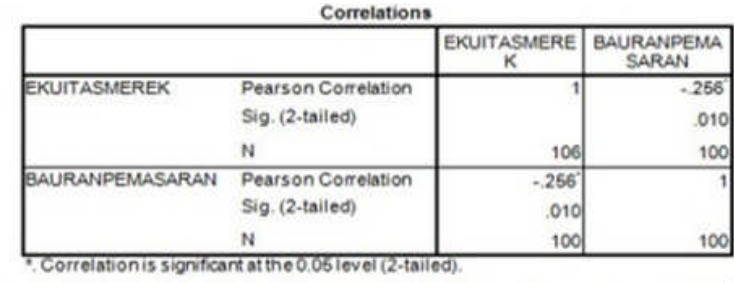

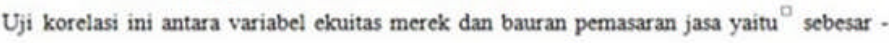

).256 berarti hubungan diantara keduanya negatif dan sukup.

1. Persamaan Struktural dari Diagram Jalur sebagai berikut:

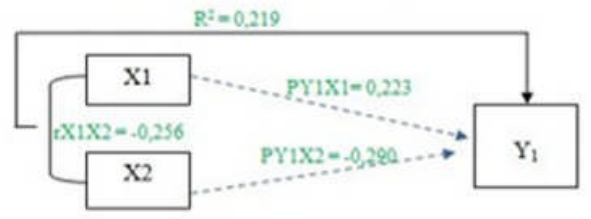




\section{Kesimpulan Hasil Rengujian} Struktur 1

\begin{tabular}{|c|r|r|r|c|}
\hline & Beta & \multicolumn{1}{|c|}{$\mathrm{T}$} & \multicolumn{1}{|c|}{ Sig } & Keputusan \\
\hline $\mathrm{Y}_{1} \mathrm{X}_{1}$ & 0,223 & 2,345 & 0,021 & Diterima \\
\hline $\mathrm{Y}_{1} \mathrm{X}_{2}$ & $-0,290$ & $-3,048$ & 0,003 & Diterima \\
\hline
\end{tabular}

The table above shows that there is a significant path analysis of brand equity variables and service marketing mix variable to customer satisfaction. So obtained

Structural Equation 1: $\mathrm{Y}_{1}=0,223 \mathrm{X}_{1}$ $0,290 \mathrm{X}_{2}$

From the results of the path diagram above the following conclusions are obtained:

1) $\mathrm{PY}_{1} \mathrm{X}_{1}$ with a value of $0.223=$ the effect of brand equity variables on customer satisfaction of 0.223 or $22.3 \%$. This means that if the brand equity variable increases by 1 percent, the average customer satisfaction also rises by 0.223 .

2) $\mathrm{PY}_{1} \mathrm{X}_{2}$ with a value of $-0.290=$ the effect of service marketing mix variables on customer satisfaction of -0.290 or $29 \%$. means that if the service marketing mix goes up 1 percent, it can mean the average satisfaction drops 0.290 .

3) Effect of variable brand equity and the marketing mix of services together (simultaneously) to customer satisfaction of R2 value of 0.219 or $21.9 \%$. The value of $\mathrm{rX} 1 \mathrm{X} 2$ of -0.256 means that the relationship of brand equity variables with the marketing mix of -0.256 , can be interpreted as the relationship between the two is negative and sufficient

\section{Hypothesis Test Results \\ Test $t$ Variable Brand Equity to Customer Loyalty}

Freedom (DK) n-2 then 100-2 $=98$, then the value of $\mathrm{t}$ table $=1.66055$

$\mathrm{T}$ value of $2.047>1.66055$ and the significance value ( $\mathrm{sig}$ ) of $0.043<0.05$ then $\mathrm{H} 0$ is rejected and $\mathrm{H} 1$ is accepted. That is to say there is a linear relationship or there is significant influence between brand equity variables on nasabh loyalty.

T test Variable marketing mix on Customer Loyalty

$\mathrm{T}$ value of -2.155 and the significance number (sig) of $0.034<0.05$ then $\mathrm{H} 0$ is rejected and $\mathrm{H} 1$ is accepted. It can be concluded that a linear or captured relationship significant influence between marketing new variables on customer loyalty.

\section{T test Variable customer satisfaction with customer loyalty}

$\mathrm{T}$ value of -2.737 and the significance number $(\mathrm{sig})$ of $0.007<0.05$ then $\mathrm{H} 0$ is rejected and $\mathrm{H} 1$ is accepted. That is to say there is a linear or existing relationship significant differences between nasabah satisfaction variables on customer loyalty.

\section{Test Results F Variable Brand} Equity, Service Marketing Mix and Customer Satisfaction Together (Simultaneously) Against Customer Loyalty.

Research F $10.981>$ from F Table of 2.70. and a significance value of 0,000 $<0.05$. Then $\mathrm{H} 0$ is rejected and $\mathrm{H} 1$ is accepted. This means that there is a linear relationship and significant influence between brand equity variables, service marketing mix and customer satisfaction together with customer loyalty.

\section{The most influential variable}

The variable that is very influential or dominant on customer loyalty is the service satisfaction variable with a beta 
value of -0.273 or $27.3 \%$.

\section{Coefficient of Determination $\left(\mathbf{R}^{2}\right)$}

$\mathrm{R} 2$ value of 0.255 , meaning

that the model has the ability to explain

\section{Kesimpulan basil penguian Struktur 2}

\begin{tabular}{|l|r|r|r|l|}
\hline & \multicolumn{1}{|c|}{ Beta } & \multicolumn{1}{|c|}{ T } & \multicolumn{1}{l|}{ Sig } & Keputusan \\
\hline Y2X1 & 0,189 & 2,047 & 0,043 & Diterima \\
\hline Y2X2 & $-0,215$ & $-2,155$ & 0,034 & Diterima \\
\hline Y2Y1 & $-0,273$ & $-2,737$ & 0,007 & Diterima \\
\hline
\end{tabular}

variations brand equity, service marketing mix and customer satisfaction with loyalty customers at $25.5 \%$. While the sis is $74.5 \%$ explained by variables others are not included in the model.

\section{a. Persamaan Struktural dari Diagram Jalur sebagai berikut:}

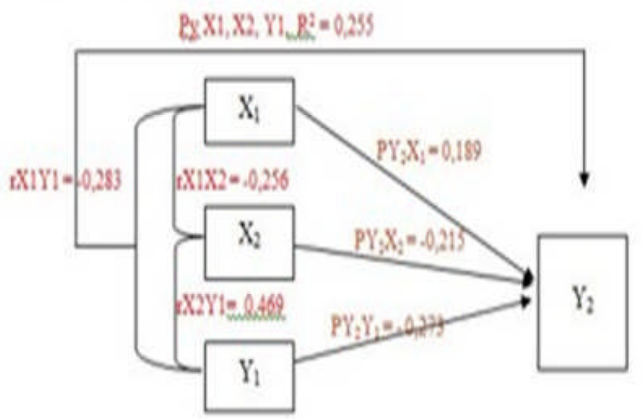

From the results of the path diagram above the following conclusions are obtained:

1. $\mathrm{PY}_{2} \mathrm{X}_{1}$ with a value of 0.189 means the influence of brand equity variables on customer loyalty of 0.189 or $18.9 \%$. which means that if the brand equity variable increases by 1 percent, the average customer loyalty also rises by 0.189.

2. $\mathrm{PY}_{2} \mathrm{X}_{2}$ with a value of -0.215 means the effect of the service marketing mix variable on customer loyalty of 0.215 or $21.5 \%$. means that if the service marketing mix increases by 1 percent, the average customer loyalty will decrease by 0.215 .

3. $\mathrm{PY}_{2} \mathrm{Y}_{1}$ with a value of -0.273 means the influence of customer satisfaction variables on customer loyalty of 0.273 or $27.3 \%$. This means that if customer satisfaction increases by 1 percent, the average customer loyalty will decrease by 0.273 .

4. The effect of brand equity variables, service marketing mix and customer satisfaction together (simultaneous) on loyalty of R2 is 0.255 or $25.5 \%$.
5. The value of $\mathrm{rX} 1 \mathrm{X} 2$ of -0.256 means the relationship of brand equity variables with the service marketing mix of -0.256 , this states the relationship between the two is negative and sufficient.

6. The value of $\mathrm{rX1Y} 1$ of -0.283 means that the relationship between brand equity variables and customer satisfaction is -0.283 , this states the relationship between the two is negative and sufficient.

The $\mathrm{rX} 2 \mathrm{Y} 1$ value of 0.469 means that the relationship between the variable marketing service mix and customer satisfaction is 0.469 , this indicates the relationship between the two is positive and sufficient.

Test Results of Effect of Brand Equity, Service Marketing Mix on Customer Loyalty through Customer Satisfaction Complete equation of structure 1 and structure 2

$$
\begin{aligned}
& Y 1=0,223 X_{1}-0,290 X_{2} \\
& Y 2=0,189 X_{1}-0,215 X_{2}-0,273 \\
& Y_{1}
\end{aligned}
$$




\section{1) Direct effect}

The direct effect of brand equity on customer satisfaction $=$ $\mathrm{X} 1 \rightarrow \mathrm{Y} 1=0.223$

The direct effect of service marketing smell on customer satisfaction $=\mathrm{X} 2 \rightarrow \mathrm{Y} 1=-0.290$

The direct effect of brand equity on customer loyalty $=\mathrm{X} 1 \rightarrow \mathrm{Y} 2=$ 0.189

Direct influence of service marketing odor on customer loyalty $=\mathrm{X} 2 \rightarrow \mathrm{Y} 2=-0,215$

The direct influence of customer satisfaction on customer loyalty $=$ $\mathrm{Y} 1 \rightarrow \mathrm{Y} 2=-0,273$

2) Undirect effect

The indirect effect of brand equity on customer loyalty through customer satisfaction

$\mathrm{X} 1 \rightarrow \mathrm{Y} 1 \rightarrow \mathrm{Y} 2=0.223 \times(-0.273)$ $=-0.06088$

The indirect effect of the marketing mix of services on customer loyalty through customer satisfaction

$\mathrm{X} 2 \rightarrow \mathrm{Y} 1 \rightarrow \mathrm{Y} 2=(-0,290) \times(-$ $0,273)=0.07917$

3) Total Effect

The effect of brand equity on customer loyalty through customer satisfaction

$0.223+(-0.06088)=0.283879$

Effect of service marketing mix on customer loyalty through customer satisfaction

$(-0,290)+0.07917=-0.21083$

\section{CONCLUSION}

1) Effect of Brand Equity and Service Marketing Mix on Customer Satisfaction $\mathrm{H} 1=$ Effect of brand equity on customer satisfaction.

The results of the $t$ test calculation of brand equity variables obtained $t$ value of research amounted to 2.544> from t table amounted to 1.66055 . The significance number (sig) obtained was $0.013<0.05$.
This means that brand equity variables significantly influence customer satisfaction.

$\mathrm{H} 2$ = Effect of service marketing mix on customer satisfaction.

The results of the calculation of the $t$ test of the service marketing mix variable obtained $t$ value of research amounting to $6,834>$ from $t$ table of 1.66055. The significance number (sig) obtained was $0,000<0.05$. This means that the marketing mix variable significantly influences customer satisfaction

H3 = Effect of brand equity and service marketing mix together (simultaneously) on customer satisfaction.

The results of the $\mathrm{F}$ test calculation obtained the F figure of 29,027> from the $\mathrm{F}$ Table of 3.09. And the significance number (sig) in the ANOVA table is $0,000<0.05$. This means that the variable brand equity and service mix mix simultaneously (simultaneously) effect on customer satisfaction.

2) Effect of Brand Equity, Service Marketing Mix and Customer Satisfaction on Customer Loyalty H1 = Effect of brand equity on customer loyalty

The results of the $t$ test calculation of brand equity variables obtained $t$ value of research is $1.752>$ from $t$ table of 1.66055. The significance number (sig) in the ANOVA table is $0.002<0.05$. This means that their brand variable has a significant effect on customer loyalty.

$\mathrm{H} 2$ = Effect of service marketing mix on customer loyalty

The results of the $t$ test calculations obtained $t$ number of research is $8,264>$ from $t$ table of 1,66055 . The significance number (sig) in the ANOVA table is $0,000<0.05$. This means that the service marketing mix variable significantly influences customer loyalty.

H3 = The effect of customer satisfaction on customer loyalty

The results of the $t$ test calculations obtained the number of research $t$ is 
$3,284>$ from $t$ table of 1,66055 . The significance number (sig) in the ANOVA table is $0.001<0.05$. This means that customer satisfaction significantly influences customer loyalty.

$\mathrm{H} 4$ = Effect of brand equity, service marketing mix and customer satisfaction together (simultaneously) on customer loyalty

The results of the $\mathrm{F}$ test calculations obtained F study number 59,747 > from the $\mathrm{F}$ Table of 2.70. And the significance number (sig) in the ANOVA table is

\section{REFERENCES}

Bank Indonesia, Statistik Perbankan Indonesia (2013), Volume 11 No. 10, ISSN: 2084-2954, Jakarta: Bank Indonesia.

Darmadi Durianto, (2001). Strategi Menaklukan Pasar. Jakarta: Gramedia Pustaka Utama.

Ety Rochaety dkk, (2007). Metodologi Penelitian Bisnis Dengan Aplikasi SPSS. Jakarta, Mitra Wacana Media..

Fandy Tjiptono \& Gregorius Chandra (2007). Service, Quality \& Satisfaction. Edisi 2, Yogyakarta: Penerbit Andi.

Fandy Tjiptono (2011). Manajemen \& Strategi Merek. Yogyakarta: Penerbit Andi.

Hawskins, Mothersbaugh \& Best (2007). Consumer Behaviour, Building Marketing Strategy. Mc GrawHill,

Hooley, Graham J., Piercy, Nigel F \& Nicouland, Brigitte (2008). Marketing Strategy and Competition Positioning, Fourth Edition, Pearson Education Limited.
$0,000<0.05$. This means that the variable brand equity, service marketing mix and customer satisfaction have a joint (simultaneous) effect on customer loyalty.

3) The most influential variables

The most influential or dominant variable on customer loyalty is the service marketing mix variable with a beta value of 0.611 or $61.1 \%$
Imam Ghazali (2006). Aplikasi Analisis Multivariate dengan Program SPSS, Semarang, Badan Penerbit UNDIP.

Jonathan Sarwono (2007). Analisis Data Penelitian Menggunakan SPSS, Yogyakarta, Penerbit ANDI.

Keller, Kevin Lane (2008). Strategic Brand Management, Building, measuring and managing Brand Equity, third edition, Pearson Education International.

Kotler, Philip \& Amstrong, Gary (2008). Prinsip-prinsip pemasaran. Jakarta: Erlangga.

Kotler, Philip \& Keller, Kevin Lane (2009).

Management $13^{\text {th }}$ Marketing Pearson Education International

Kumar, Anil (1999). Bank Marketing Mix: New Strategy in Today Banking Sector, BPR Technologia: A Journal of Science, Tehnology \& Management, Volume 2, 2013. 
LCCI. How to Pass Public Relations, Third Level, Britain: LCCI Examination Board,

Nachrowi D Nachrowi , Hardius Usman (2006), Pendekatan Ekonometrika Untuk Analisis Ekonomi dan Keuangan , Jakarta, Lembaga Penerbit FEUI.

Philip Kotler (2003). Marketing insight from $A$ to $Z: \quad 80$ Concepts every manager needs to know", New Jersey: John Wiley \& Sons, Inc,

Rangkuti, Freddy (2009). The power of Brands, Teknik Mengelola Brand Equity dan Strategi Pengembangan Merek+ analisis kasus dengan SPSS. Jakarta: PT. Gramedia Pustaka Utama,

Sambas Ali Muhidin (2007). Analisis Korelasi, Regresi dan Jalur dalam Penelitian. Bandung, Pustaka Setia.
Sekaran, Uma (2006). Research Method for Business. Jakarta: Salemba Empat,

Singgih Santoso (2000). SPSS (Statistical Product and Service Solution). Jakarta, Elex Media Komputindo.

Sugiyono, Danang (2009). Statistika Untuk Penelitian. Cetakan ke empat, Bandung: Alfabeta,

Sunyoto, Danang (2012). Dasardasar Mananejemen Pemasaran. Yogyakarta: penerbit CAPS,

Umar, Husein. (2010). Riset Pemasaran \& Perilaku konsumen, Cetakan kelima. Jakarta: Pt. Gramedia Pustaka Utama,

Wells, William, Moriarty, Sandra \& Burnett (2006). Advertising, Principles \& Practice, $7^{\text {th }}$ edition, Pearson Education International. 